\title{
Carcass and meat of two genetic groups of cattle fed two levels of grass-Convert silage in feedlot
}

\section{Carcaça e carne de dois grupos genéticos de bovinos alimentados com dois níveis de silagem de capim-Convert em confinamento}

\author{
Regis Luis Missio ${ }^{1 *}$; Darlene Pereira da Silva²; Emerson Alexandrino ${ }^{3}$; \\ João Restle ${ }^{4}$; Joaquim José de Paula Neto²; José Messias de Rezende ${ }^{2}$; \\ Jonahtan Chaves $\mathrm{Melo}^{2}$; André Augusto Marinho Silva ${ }^{5}$; Tatielle Duarte e Duarte ${ }^{2}$
}

\begin{abstract}
Assessment of carcass and meat characteristics of Nellore young bulls or dairy crossbred young bulls fed two levels of grass-Convert silage in the rations (400 and $100 \mathrm{~g} \mathrm{~kg}^{-1}$ of dry matter). Sixteen Nellore young bulls and 16 dual-purpose dairy young bulls (Holstein x Gir and Holstein x Guzerá) with average initial body weight of $378.8 \pm 13.8 \mathrm{~kg}$ were used. The experimental design was completely randomized with treatments in a $2 \times 2$ factorial arrangement. The proportion of silage and the genetic group did not change the percentage of muscle, fat and bone of the carcass. The yield of the primary commercial cuts was not altered by the level of silage. The pistol cut weight was higher in Nellore young bulls compared to dairy crossbred young bulls (125.8 vs. $119.5 \mathrm{~kg})$, while the relative weight of short ribs was higher in dairy crossbreds (11.9 vs. $11.5 \%$ ). Only the muscle cut of the pistol was altered by silage proportion in the rations, being higher in those with the lowest proportion of grass silage. On the other hand, only the relative weight of flat, rump cap and edible lean trims were altered by genetic group, which were higher in Nellore young bulls. Among the characteristics of the meat, only marbling was significantly changed, being higher in dairy crossbreds fed rations with a lower grass-silage proportion. The genetic group did not alter the other meat characteristics. Nellore young bulls produce carcasses with higher yield of valuable meat cuts in relation to dairy crossbred young bulls.
\end{abstract}

Key words: Commercial cuts. Prime cuts. Meat quality. Rump cap.

\section{Resumo}

Objetivou-se avaliar as características de carcaça e carne de tourinhos da raça Nelore ou mestiços leiteiros de dupla aptidão (Holandês x Gir e Holandês x Guzerá) alimentados com dois níveis de silagem de capim-Convert nas dietas (400 e $100 \mathrm{~g} \mathrm{~kg}^{-1}$ de matéria seca). Foram utilizados 16 tourinhos da raça Nelore e 16 tourinhos mestiços de origem leiteira, com peso médio inicial de $378,8 \pm 13,8 \mathrm{~kg}$. O delineamento experimental foi o inteiramente casualizado com os tratamentos em arranjo fatorial $2 \times 2$. A proporção de silagem e o grupo genético dos animais não alteraram a percentagem de músculo, gordura

\footnotetext{
${ }^{1}$ Prof., Departamento de Agronomia, Universidade Tecnológica Federal do Paraná, UTFPR, Pato Branco, PR, Brasil. E-mail: regisluismissio@gmail.com

2 Discentes do Curso de Mestrado, Programa de Pós-Graduação em Ciência Animal Tropical, Universidade Federal do Tocantins, UFT, Araguaína, TO, Brasil. E-mail: darlene_zootec@hotmail.com; jneto@zootecnista.com.br; jonahtancmelo@hotmail.com; messyas10@hotmail.com; tatieleduarte@hotmail.com

3 Prof., Escola de Medicina Veterinária e Zootecnia, UFT, Araguaína, TO, Brasil. E-mail: e_alexandrino@yahoo.com.br

${ }^{4}$ Prof., Programa de Pós-Graduação em Zootecnia da EMVZ, Universidade Federal de Goiás, UFG, Goiânia, GO, Brasil. E-mail: jorestle@terra.com.br

5 Discente do Curso de Zootecnia, UFT, Araguaína, TO, Brasil. E-mail: andre_augusto89@hotmail.com

* Author for correspondence
} 
e osso da carcaça. O rendimento dos cortes comerciais primários não foi alterado pelo nível de silagem. O peso do traseiro especial foi superior nos tourinhos Nelore em relação aos mestiços leiteiros $(125,8$ vs $119,5 \mathrm{~kg})$, enquanto o peso relativo da ponta de agulha foi superior nos mestiços leiteiros $(11,9 v s$ $11,5 \%)$. Somente o corte denominado "músculo" do traseiro especial foi alterado pela proporção de silagem nas rações, sendo superior naquelas com menor proporção de volumoso. Por outro lado, apenas o peso relativo do coxão duro, picanha e recortes comestíveis foram alterados pelo grupo genético, que foram superiores nos animais da raça Nelore. Dentre as características da carne, apenas o marmoreio foi alterado significativamente, sendo superior nos mestiços leiteiros que receberam rações com menor proporção de silagem. $\mathrm{O}$ grupo genético dos animais não alterou as demais características da carne. Tourinhos da raça Nelore produzem carcaças com maior rendimento de cortes nobres em relação aos mestiços leiteiros.

Palavras-chave: Cortes comerciais. Cortes nobres. Picanha. Qualidade da carne.

\section{Introduction}

Feeding costs during confinement can be reduced by the use of high quality forages, which is not always possible because of the potential of agricultural production systems. This has accredited tropical grasses as an alternative food, which requires the amount of concentrate in diets to be increased, and in turn, increases feeding costs (CRUZ et al., 2014). However, data related to the use of grass silage in the ration of feedlot cattle are still limited, especially regarding the effect on carcass characteristics and beef meat. In general, studies have shown that increasing the proportion of traditional silages (maize and sorghum) in the diet may harm important carcass characteristics (thawing loss, physiological maturity and pistol cut proportion) and meat characteristics (tenderness, texture and color) (SILVEIRA et al., 2009; MISSIO et al., 2010). However, some studies (CRUZ et al., 2014, 2015a, 2015b) have shown that diets with high concentrate levels did not affect the performance and carcass characteristics of feedlot beef cattle, wherein the higher grass silage content of diets ( 350 vs. $190 \mathrm{~g} / \mathrm{kg}$ ) reduced feeding cost.

The genotype of the animal is another important factor, since it is a major determinant of the productive potential during feedlot; it also interacts with diets and can determine divergent responses as different dietary energy levels are used. Silveira et al. (2009) found that increasing the concentrate content reduced liquid loss in Charolais young bulls, but not in Nellore young bulls. Menezes et al. (2005) found that subcutaneous fat thickness was not changed in Charolais young bulls' carcass, but this characteristic showed quadratic variation with the advance of concentrate in the ration of Nellore young bulls. According to Putrino et al. (2007), Zebu are less adapted to high concentrate levels compared to taurine, which may lead to differences in animal performance, carcass, and meat characteristics. However, an incipient number of results are presented in literature in relation to carcass and meat characteristics from animals of different genetic groups fed with high levels of concentrate, making it difficult to establish the most appropriate nutritional strategies for the different genetic groups.

The objective of this study was to evaluate carcass and meat characteristics of Nellore young bulls and dairy crossbred young bulls fed two levels of grass-Convert silage in the rations.

\section{Material and Methods}

The study was conducted between June and September 2012, at the Federal University of Tocantins, Araguaína Campus (07 $17^{\circ}$ ' $28^{\prime}$ ' S $48^{\circ}$ 12 ' 26" W). Sixteen Nellore young bulls and 16 dual-purpose dairy young bulls (Holstein x Gir and Holstein x Guzerá) with initial body weight of 378.8 $\pm 13.8 \mathrm{~kg}$ and initial age of 24 months were used. The animals were confined in partially covered stalls $\left(16 \mathrm{~m}^{2}\right)$, equipped with feeders and drinkers, containing two animals of similar genetic group per 
stall. The experimental period was 78 days and the period of adaptation to the facilities and diets (Table 1) was of 15 days. The experimental procedures were approved by the Ethics Committee on Animal Experimentation of Federal University of Tocantins, under number 23101.000785/2.014-91.

The animals were fed at 0800 and 1400 ad libitum, adjusted to allow $10 \%$ orts of offered feed (dry matter basis). Animals fasted for 14-16 $\mathrm{h}$ were weighed at the beginning and end of the evaluation period. To obtain the average feed intake, feed and orts were weighed daily. Samples of ingredients and orts from each animal and ingredients of concentrates feed from mixture preparations were collected weekly to provide representative samples. The samples were pre-dried in a forced-air ventilation oven at $55^{\circ} \mathrm{C}$ for $72 \mathrm{~h}$ and processed in a Wiley mill with a $1-\mathrm{mm}$ sieve. Subsequently, the food chemical composition was determined and the chemical composition of the rations was calculated (Table 1). Dry matter and crude protein content were determined according to AOAC (1995). Neutral detergent fiber content was determined according to Van Soest et al. (1991). Total digestible nutrients (TDN) was determined according to Sniffen et al. (1992): TDN = digestible crude protein + digestible neutral detergent fiber + digestible non-fibrous carbohydrates $+(2.25 \mathrm{x}$ digestible ether extract).

Table 1. Composition of experimental diets.

\begin{tabular}{|c|c|c|}
\hline \multirow{2}{*}{ Items ( $\mathrm{g} \mathrm{kg}^{-1}$ dry matter) } & \multicolumn{2}{|c|}{ Diet silage proportion $\left(\mathrm{g} \mathrm{kg}^{-1}\right)$} \\
\hline & 400 & 100 \\
\hline \multicolumn{3}{|c|}{ Composition of diets } \\
\hline Grass silage Convert HD 364 & 403.0 & 105.3 \\
\hline Ground corn & 437.2 & 767.3 \\
\hline Soybean meal & 122.4 & 85.9 \\
\hline Limestone & 7.2 & 11.2 \\
\hline Livestock urea & 7.2 & 8,1 \\
\hline Ammonium sulfate & 0.9 & 0.8 \\
\hline Salt & 5.4 & 5.4 \\
\hline Mineral mix ${ }^{1}$ & 16.7 & 16.1 \\
\hline \multicolumn{3}{|c|}{ Chemical composition } \\
\hline Dry matter & 626.2 & 822.3 \\
\hline Crude protein & 146.1 & 149.1 \\
\hline TDN & 688.3 & 800.1 \\
\hline Neutral detergent fiber & 403.2 & 243.1 \\
\hline
\end{tabular}

${ }^{1}$ Composition $\left(\mathrm{g} \mathrm{kg}^{-1}\right)=\mathrm{Na}: 150, \mathrm{Ca}: 118, \mathrm{P}: 90, \mathrm{Mg}: 7, \mathrm{~S}: 12, \mathrm{~N}: 10, \mathrm{Zn}: 3.6, \mathrm{Cu}: 1.73, \mathrm{Co:}$ 0.2, Mn: 0.1, I: 0.015, Se: 0.002.

The animals were slaughtered in a commercial slaughterhouse approved by the Brazilian Federal Inspection Service (Serviço de Inspeção Federal, SIF), following a normal slaughter line flow. Slaughter weight was of 473.6 and $479.9 \mathrm{~kg}$ for Nellore and dual-purpose dairy young bulls fed with $400 \mathrm{~g} \mathrm{~kg}^{-1}$ of silage in their ration, respectively. Nellore and dual-purpose dairy young bulls fed with $100 \mathrm{~g} \mathrm{~kg}^{-1}$ of silage in the rations had slaughter weights of 476.1 and $486.1 \mathrm{~kg}$, respectively. Prior to slaughter, the animals were fasted for 14-16 h. After slaughter, the carcasses were identified, divided in half, weighed, washed, and kept in a cold chamber for $24 \mathrm{~h}$ at a temperature varying between 0 and $2^{\circ} \mathrm{C}$, and then weighed again after cooling. Fat thickness was measured at the 11 th rib with the aid of calipers. The cold carcass weight and fat thickness were of $265.3 \mathrm{~kg}, 4.2 \mathrm{~mm}, 262.3 \mathrm{~kg}$ and $3.3 \mathrm{~mm}$ for Nellore and dairy crossbreed young bulls fed with $400 \mathrm{~g} \mathrm{~kg}$ of silage in their diet, and $267.8 \mathrm{~kg}, 3.9$ 
$\mathrm{mm}$, and $269.95 \mathrm{~kg} 4.1 \mathrm{~mm}$ for Nellore and dairy crossbreed young bulls fed with $100 \mathrm{~g} \mathrm{~kg}^{-1}$ of silage, respectively.

The left half of the carcass was separated into primary cuts, with the forequarter separated from the pistol cut and short ribs between the $5^{\text {th }}$ and $6^{\text {th }}$ ribs, which included neck, shoulder, arm, and five ribs. Through the rib cut at $22 \mathrm{~cm}$ of the vertebral column, the pistol cut was separated from the short ribs, which included the ribs from the sixth rib onward, plus the abdominal muscles. After that, the primary cuts were weighed, and the relative weight of the half carcass was determined.

In the right half of the carcass, the $\mathrm{HH}$ section was removed and dissected into muscle, fat, and bone, and weighed to estimate the proportion of each in the carcass (HANKINS; HOWE, 1946). On the surface of the cranial portion of the HH section, after $30 \mathrm{~min}$ of exposure to air, we evaluated the color $(1=$ dark, $2=$ dark red, $3=$ slightly dark red, 4 $=$ red, and $5=$ bright red $)$, texture $(1=$ very coarse, $2=$ coarse, $3=$ slightly coarse, $4=$ thin, and $5=$ very thin), and marbling ( 1 to $3=$ traces, 4 to $6=$ light, 7 to $9=$ small, 10 to $12=$ medium, 13 to 15 $=$ moderate, and 16 to $18=$ abundant) according to the method described by Müller (1987). After, the longissimus dorsi muscle was packed, identified and frozen at $-18{ }^{\circ} \mathrm{C}$. After 30 days, a steak was removed from each longissimus dorsi muscle with $2.5 \mathrm{~cm}$ thickness, weighed and thawed on aluminum pans for 12 hours at $4{ }^{\circ} \mathrm{C}$ and again weighed to determine weight loss during thawing. After thawing, the steaks were placed in pre weighed aluminum pans and baked in an electric oven until internal temperature reached $70{ }^{\circ} \mathrm{C}$. After that, the steaks were weighed with and without the tray to obtain fluid loss during the cooking process. Shear strength of muscle fibers was determined in steaks which were cooked and cooled for 24 hours at $4{ }^{\circ} \mathrm{C}$. Eight circular pieces were extracted with $1.0 \mathrm{~cm}^{2}$ extracted from each stake, which were transversely cut to the direction of muscle fibers with the WarnerBratzler Shear machine.

The experimental design used was completely randomized with treatments in a $2 \times 2$ factorial arrangement, using eight repetitions. Shapiro Wilk and Cochran \& Bartlett's tests were performed, respectively, to evaluate the normality and homogeneity of variances, and whenever necessary, the data were transformed by $\log ^{2}$. After the assumptions of normality and homogeneity of variances, data were submitted to analysis of variance and Pearson correlation $(\alpha=5 \%)$. The mathematical model was represented by: $\gamma_{\mathrm{ij}}=\mu+$ $\tau_{\mathrm{i}}+£_{\mathrm{j}}+\tau_{\mathrm{i}} \mathfrak{£}_{\mathrm{j}}+\varepsilon_{\mathrm{ij}}$, where: $\gamma_{\mathrm{ij}}=$ dependent variable; $\mu=$ general mean; $\tau_{\mathrm{i}}=$ silage proportion effect; $£_{\mathrm{j}}=$ genotype effect; $\tau_{i}{ }^{*} £_{j}=$ interaction between silage proportion and genotype; $\varepsilon_{\mathrm{ij}}=$ experimental error.

\section{Results and Discussion}

There was no interaction $(\mathrm{P}>0.05)$ between grass-Convert silage levels and genetic group of animals for the evaluated variables, except for meat marbling. The carcass physical composition was not changed $(\mathrm{P}>0.05)$ by the silage proportion in diets and genetic group of animals (Table 2), which can be attributed to the similar body weight at slaughtering. The results were similar to those observed by Silveira et al. (2009) and Missio et al. (2010), wich after evaluating concentrate levels for feedlot cattle found no change in carcass physical composition, which was attributed to the similar slaughter weight. However, it should be expected a higher fat content for the lowest silage proportion, since the higher energy content tends to increase body fat storage (PETHICK et al., 2004). However, this hypothesis probably did not materialize because of the high proportion of concentrate used, with no energy limitation for the deposition of body fat. 
Table 2. Carcasses characteristics of Nellore (N) young bulls or dairy crossbreed (DC) fed with grass silage proportions (SP) in the diet.

\begin{tabular}{|c|c|c|c|c|c|c|c|c|}
\hline \multirow{2}{*}{ Items } & \multicolumn{2}{|c|}{400} & \multicolumn{2}{|c|}{100} & \multirow{2}{*}{$\mathrm{CV}$} & \multicolumn{3}{|c|}{ Variation sources } \\
\hline & $\mathrm{N}$ & $\mathrm{DC}$ & $\mathrm{N}$ & $\mathrm{DC}$ & & SP & GG & $\mathrm{SP} * \mathrm{GG}$ \\
\hline \multicolumn{9}{|c|}{ Physical composition } \\
\hline Muscle, $\mathrm{kg}$ & 174.00 & 169.40 & 178.80 & 174.00 & 8.50 & 0.388 & 0.390 & 0.992 \\
\hline Fat, $\mathrm{kg}$ & 50.80 & 54.10 & 48.60 & 50.80 & 12.61 & 0.242 & 0.251 & 0.819 \\
\hline Bone, kg & 40.50 & 38.80 & 40.40 & 39.50 & 11.24 & 0.846 & 0.437 & 0.802 \\
\hline Muscle, \% & 65.59 & 64.58 & 66.77 & 65.83 & 4.02 & 0.202 & 0.750 & 0.794 \\
\hline Fat, \% & 19.15 & 20.63 & 18.15 & 19.22 & 13.86 & 0.203 & 0.697 & 0.908 \\
\hline Bone, $\%$ & 15.27 & 14.79 & 15.09 & 14.95 & 9.75 & 0.974 & 0.889 & 0.795 \\
\hline Muscle/Bone & 4.30 & 4.37 & 4.43 & 4.41 & 10.93 & 0.723 & 0.815 & 0.655 \\
\hline Muscle + fat/bone & 5.55 & 5.76 & 5.63 & 5.69 & 11.31 & 0.864 & 0.925 & 0.666 \\
\hline \multicolumn{9}{|c|}{ Commercial cuts } \\
\hline Forequarter, kg & 112.80 & 107.90 & 112.80 & 111.20 & 7.42 & 0.599 & 0.288 & 0.580 \\
\hline Forequarter, \% & 42.52 & 41.14 & 42.12 & 42.07 & 2.98 & 0.692 & 0.741 & 0.320 \\
\hline Short ribs, kg & 30.80 & 31.80 & 30.50 & 31.10 & 8.16 & 0.592 & 0.385 & 0.852 \\
\hline Short ribs, \% & 11.61 & 12.12 & 11.39 & 11.77 & 6.95 & 0.362 & 0.024 & 0.745 \\
\hline Pistol cut, kg & 124.90 & 119.20 & 126.70 & 119.80 & 6.42 & 0.692 & 0.036 & 0.835 \\
\hline Pistol cut, \% & 47.08 & 45.44 & 47.31 & 45.33 & 2.67 & 0.840 & 0.067 & 0.428 \\
\hline
\end{tabular}

400 e $100=\mathrm{g}$ of grass silage $\mathrm{kg}^{-1}$ of dry matter of the diet, $\mathrm{CV}=$ coefficient of variation; $\mathrm{GG}=$ genetic group.

The similar slaughter weight and similar carcass composition among Nellore bulls and the dairy crossbred young bulls were result of similar animal performance. In general, higher animal performance is expected for beef cattle genotypes, because of their specialization for weight gain in relation to dairy cattle. This difference in animal performance alters the physical composition of the carcass due to higher rates of fat accumulation (NRC, 1996). In addition, dairy breeds usually have lower meat yield than beef cattle breeds, because of lower muscularity and higher internal fat deposition (FERNANDES et al., 2005; ALBERTÍ et al., 2008). However, those findings have generally derived from comparisons between dairy breeds and European beef cattle or European beef cattle crossbreds. In this respect, in the study of McGee et al. (2008), the Charolais x Holstein-Friesian crossbred had a higher muscle proportion compared to Holstein or HolsteinFrisian, which stood out for their bone and fat proportions, respectively. Comparisons between dairy cattle crossbreds and zebu, however, do not follow the same logic. This is because of Zebu's lower potential for weight gain and lower muscle proportion in relation to European beef cattle genotypes (LEME et al., 2000; VAZ; RESTLE, 2001), resulting in similarities in finishing and muscularity characteristics of carcass between dairy crossbreeds and zebu cattle (ROCHA JÚNIOR et al., 2010).

The level of silage did not affect $(\mathrm{P}>0.05)$ the weights and primary commercial cuts proportions (Table 2). These results can be attributed to the similar body development of the animals, a fact evidenced for the similar body weight and age at slaughter. Differently from the present study, Missio et al. (2010) verified an increase of pistol cut proportion with the increase of concentrated content in diets, which was attributed to slaughter age which reduced with the increase in the concentrate level. However, it is worth highlighting that differences in the primary commercial cuts of cattle fed with different forage/concentrated proportions have not been found in diets with high concentrate content (CRUZ et al., 2015a). 
The dairy crossbred young bulls showed a lower $(\mathrm{P}<0.05)$ pistol-cut weight and a higher forequarter proportion compared to Nellore young bulls. These results can be attributed to the different selection objectives applied to the dairy breeds, which seek to increase the ingestion and respiratory capacity. Similar results were obtained by Rocha Júnior et al. (2010), who found that Nellore had higher pistol cut proportion and lower forequarter proportions in relation to $1 / 2$ Holstein 1/4 Gir 1/4 Nellore young bulls, which can be attributed to the aptitude of the Nellore for meat production. Moreover, Alves et al. (2004) found no change in weight and proportion of primary commercial cuts in carcass of Holstein x Gir young bulls, Holstein x Guzerá or Indubrasil, which was justified by the animal's tendency to maintain balance between its front and hind parts.

Among the secondary commercial cuts, only weight and muscle ratio were altered $(\mathrm{P}<0.05)$ by the silage levels, decreasing with the increment in silage participation in the diets (Table 3 and 4). The factors of cause and effect determining these results, however, were not evidenced. It is worth mention the incipient number of results in literature regarding the evaluation of secondary commercial cuts, especially in light of silage/concentrate in the rations. In one of the few studies found, Cruz et al. (2015b) reported no change in weight and the proportion of commercial cuts from pistol cut in young bulls fed with different proportions of grass silage in the rations ( $35 \%$ and $19 \%$ ). It is important to note that some studies have shown that the effect of diets on secondary commercial cuts were consistent only when carcass weight was changed (MIOTTO et al., 2012). These authors found that the inclusion of babassu mesocarp bran $(0,25,50,75$ and $100 \%)$ in diets for dairy crossbred young bulls reduced carcass weight, which was accompanied by the reduction of tenderloin steak weight, sirloin steak, knuckle and fat clippings.

Table 3. Secondary commercial cuts of Nellore (N) young bulls or dairy crossbreed dairy (DC) fed with grass silage proportions (SP) in the diet.

\begin{tabular}{|c|c|c|c|c|c|c|c|c|}
\hline \multirow{2}{*}{ Items, $\mathrm{kg}$} & \multicolumn{2}{|c|}{400} & \multicolumn{2}{|c|}{100} & \multirow{2}{*}{$\mathrm{CV}$} & \multicolumn{3}{|c|}{ Variation sources } \\
\hline & $\mathrm{N}$ & $\mathrm{DC}$ & $\mathrm{N}$ & $\mathrm{DC}$ & & $\mathrm{SP}$ & GG & $\mathrm{SP}^{*} \mathrm{GG}$ \\
\hline Topside & 9.24 & 9.13 & 9.73 & 8.94 & 7.15 & 0.523 & 0.071 & 0.165 \\
\hline Flat & 5.37 & 4.76 & 5.40 & 4.92 & 8.28 & 0.555 & 0.001 & 0.667 \\
\hline Striploin & 8.01 & 7.97 & 7.41 & 7.75 & 21.76 & 0.509 & 0.810 & 0.763 \\
\hline Knuckle & 5.27 & 5.03 & 5.42 & 5.11 & 7.22 & 0.408 & 0.053 & 0.802 \\
\hline Muscle & 4.23 & 3.91 & 4.45 & 4.38 & 9.67 & 0.030 & 0.213 & 0.399 \\
\hline Rump & 3.47 & 3.36 & 3.67 & 3.42 & 9.15 & 0.295 & 0.145 & 0.610 \\
\hline Eyeround & 2.75 & 2.78 & 2.79 & 2.68 & 10.26 & 0.822 & 0.712 & 0.505 \\
\hline Filet & 2.04 & 2.05 & 1.93 & 1.93 & 12.68 & 0.646 & 0.474 & 0.441 \\
\hline Rump cap & 1.69 & 1.62 & 1.71 & 1.45 & 12.98 & 0.334 & 0.041 & 0.220 \\
\hline Tail of rump & 1.36 & 1.20 & 1.44 & 1.26 & 9.86 & 0.204 & 0.958 & 0.986 \\
\hline Striploin cap & 1.12 & 1.36 & 1.21 & 1.20 & 25.10 & 0.203 & 0.321 & 0.848 \\
\hline Skirt steak & 1.08 & 1.03 & 1.05 & 0.93 & 24.49 & 0.482 & 0.712 & 0.505 \\
\hline Rib fingers & 0.43 & 0.40 & 0.47 & 0.43 & 18.45 & 0.202 & 0.321 & 0.848 \\
\hline Baby beef & 0.32 & 0.32 & 0.21 & 0.21 & 2.44 & 0.206 & 0.964 & 0.994 \\
\hline Edible clippings & 1.63 & 1.13 & 1.40 & 1.23 & 27.29 & 0.425 & 0.037 & 0.126 \\
\hline Total & 50.22 & 47.81 & 50.12 & 47.42 & 8.04 & 0.865 & 0.094 & 0.927 \\
\hline
\end{tabular}

400 e $100=\mathrm{g}$ of grass silage $\mathrm{kg}^{-1}$ of dry matter of the diet, $\mathrm{CV}=$ coefficient of variation; $\mathrm{GG}=$ genetic group. 
The weights $(\mathrm{kg})$ of flat, rump cap, and edible clippings were higher $(\mathrm{P}<0.5)$ in pistol cuts from Nellore young bulls in relation to dairy crossbreeds (Table 3). However, when the secondary commercial cuts were expressed in relation to carcass weight, only the weights for flat and tail of rump were altered by genetic group, and were higher in Nellore carcasses (Table 4). These results can be attributed to the higher pistol-cut weight observed in this genetic group. The results were somewhat similar to those obtained by Rocha Júnior et al. (2010), who evaluated the higher value cuts of the pistol cut (sirloin and rump) and found rump weight to be higher for Nellore bulls than for dairy crossbreeds, with no difference in the proportion of these cuts related to the cold carcass weight. Alves et al. (2004), when assessing full chuck yield, full rump and flat/topside, found no change in the proportion of these cuts in relation to carcass weight between Indubrasil bulls and dairy crossbreeds.

Table 4. Secondary commercial cuts of Nellore (N) young bulls or dairy crossbreed dairy (DC) fed with grass silage proportions (SP) in the diet.

\begin{tabular}{|c|c|c|c|c|c|c|c|c|}
\hline \multirow{2}{*}{ Items, $\%$} & \multicolumn{2}{|c|}{400} & \multicolumn{2}{|c|}{100} & \multirow{2}{*}{$\mathrm{CV}$} & \multicolumn{3}{|c|}{ Variation sources } \\
\hline & $\mathrm{N}$ & $\mathrm{DC}$ & $\mathrm{N}$ & $\mathrm{DC}$ & & SP & GG & $\mathrm{SP}^{*} \mathrm{GG}$ \\
\hline Topside & 3.44 & 3.52 & 3.61 & 3.42 & 5.13 & 0.544 & 0.412 & 0.045 \\
\hline Flat & 2.00 & 1.84 & 2.00 & 1.88 & 6.32 & 0.584 & 0.003 & 0.655 \\
\hline Striploin & 2.98 & 3.07 & 2.73 & 2.94 & 19.64 & 0.364 & 0.471 & 0.766 \\
\hline Knuckle & 1.96 & 1.942 & 2.01 & 1.95 & 4.85 & 0.406 & 0.264 & 0.597 \\
\hline Muscle & 1.56 & 1.51 & 1.65 & 1.67 & 8.43 & 0.019 & 0.793 & 0.455 \\
\hline Rump & 1.29 & 1.390 & 1.36 & 1.31 & 7.97 & 0.298 & 0.583 & 0.502 \\
\hline Eyeround & 1.02 & 1.07 & 1.03 & 1.02 & 6.46 & 0.483 & 0.506 & 0.248 \\
\hline Filet & 0.76 & 0.79 & 0.77 & 0.73 & 10.44 & 0.437 & 0.941 & 0.275 \\
\hline Rump cap & 0.63 & 0.62 & 0.63 & 0.55 & 11.10 & 0.188 & 0.099 & 0.141 \\
\hline Tail of rump & 0.51 & 0.46 & 0.53 & 0.48 & 8.15 & 0.111 & 0.003 & 0.798 \\
\hline Striploin cap & 0.42 & 0.52 & 0.45 & 0.47 & 23.11 & 0.609 & 0.142 & 0.217 \\
\hline Skirt steak & 0.40 & 0.40 & 0.39 & 0.36 & 23.11 & 0.439 & 0.547 & 0.652 \\
\hline Rib fingers & 0.16 & 0.16 & 0.17 & 0.16 & 15.25 & 0.177 & 0.455 & 0.736 \\
\hline Baby beef & 0.12 & 0.12 & 0.08 & 0.08 & 2.44 & 0.206 & 0.964 & 0.994 \\
\hline Edible clippings & 0.61 & 0.44 & 0.49 & 0.473 & 27.62 & 0.422 & 0.082 & 0.129 \\
\hline Total & 17.94 & 17.75 & 17.91 & 17.50 & 4.36 & 0.630 & 0.311 & 0.711 \\
\hline
\end{tabular}

400 e $100=\mathrm{g}$ of grass silage $\mathrm{kg}^{-1}$ of dry matter of the diet, $\mathrm{CV}=$ coefficient of variation; $\mathrm{GG}=$ genetic group.

Grass silage proportion in ration and the animals' genetic group were not decisive to change $(\mathrm{P}>0.05)$ meat color and texture (Table 5). These results can be attributed to the fact that these characteristics are primarily associated with body weight and/or age of the animals. With respect to color, it is due to the amount of circulating myoglobin which increases with the advance of age (OURY et al., 2009). Texture, on the other hand is evaluated by the granulating shown on muscle surface when it is cut, since the muscle is constituted by a set of clustered muscle fibers fascicles surrounded by a thin connective tissue layer, the perimysium, and young cattle have beef with a finer texture than those of older age (MÜLLER, 1987). The results were similar to those obtained by Cruz et al. (2015b), who found no change in color and texture of meat from young bulls fed with different concentrate levels in their diet, which was attributed to similar slaughter age. Moreover, the results of this study were different from those reported by Missio et al. (2010), who found that meat color and texture benefited from the increase of concentrate level in the diet, which was attributed to reduced slaughter age. However, 
no literature information was found on the quality of dairy crossbreeds and zebu cattle. In general, we can expect a darker color for zebu meat because of its higher pre-slaughter excitability (MAGGIONI et al., 2012; PACHECO et al., 2015). Texture changes on the other hand, due to its relation with the animals' age (MÜLLER, 1987) have not been consistent in comparisons between genetic groups of cattle slaughtered with similar weight or age (SILVA et al., 2014). According to these authors, the effect of diet and genetic group has greater impact on beef texture when the animals' growth curve, deposition of body tissues and carcass physiological maturity are changed.

Table 5. Meat characteristics of Nellore (N) young bulls or dairy crossbreed (DC) fed with grass silage proportions (SP) in the diet.

\begin{tabular}{|c|c|c|c|c|c|c|c|c|}
\hline \multirow{2}{*}{ Items, $\%$} & \multicolumn{2}{|c|}{400} & \multicolumn{2}{|c|}{100} & \multirow{2}{*}{$\mathrm{CV}$} & \multicolumn{3}{|c|}{ Variation sources } \\
\hline & $\mathrm{N}$ & $\mathrm{DC}$ & $\mathrm{N}$ & $\mathrm{DC}$ & & $\mathrm{SP}$ & GG & $\mathrm{SP} * \mathrm{GG}$ \\
\hline Color, points & 2.64 & 2.74 & 3.09 & 2.47 & 19.16 & 0.662 & 0.182 & 0.070 \\
\hline Texture, points & 2.92 & 3.23 & 2.96 & 3.25 & 17.89 & 0.882 & 0.143 & 0.967 \\
\hline Marbling, points & 3.25 & 4.00 & 4.75 & 6.75 & 15.59 & 0.001 & 0.449 & 0.019 \\
\hline Shear force, $\mathrm{kg} / \mathrm{cm}^{2}$ & 4.93 & 4.82 & 5.69 & 5.33 & 24.87 & 0.503 & 0.803 & 0.893 \\
\hline Thawing loss, $\%$ & 4.59 & 5.87 & 7.78 & 4.91 & 28.94 & 0.368 & 0.448 & 0.111 \\
\hline Cooking loss, $\%$ & 21.62 & 24.33 & 24.02 & 23.90 & 19.13 & 0.975 & 0.532 & 0.745 \\
\hline
\end{tabular}

400 e $100=\mathrm{g}$ of grass silage $\mathrm{kg}^{-1}$ of dry matter of the diet, $\mathrm{CV}=$ coefficient of variation; $\mathrm{GG}=$ genetic group.

Dairy crossbreeds meat had higher marbling in animals fed diets with a lower proportion of silage, with no difference observed between genetic groups for the diet with a higher silage proportion (Table 5). Marbling variation is primarily derived from genetic factors, followed by age (and/or animal category) and nutrition (PETHICK et al., 2004). Genetic propensity (selection time), adult body size, and/or maturity type are ways through which genetic factors can lead to variation in meat marbling (PETHICK et al., 2004; RIPOLI et al., 2011). Zebu breeds usually occupy an intermediate position in relation to British and Continental breeds, while Continental breeds have lower intramuscular fat deposition in relation to British and Zebu breeds (SCHERTZ et al., 2011). On the other hand, despite some variability in the literature, dairy breeds, such as Holstein, usually have similar marbling compared to British breeds (ALBRECHT et al., 2006). With regard to nutrition, diets containing higher levels of gluconeogenic precursors generally promote increased intramuscular fat deposition, because this type of fat prefers carbons derived from glucose and lactate, whereas subcutaneous fat prefers carbon derived from acetate and acetyl units (PETHICK et al., 2004).

Shear force of muscle fibers was not affected (P $>0.05$ ) by the proportion of silage in rations and by genetic group of animals (Table 5). These results were similar to those obtained by Missio et al. (2010) and Cruz et al. (2015b), who after feeding different concentrate levels for bulls found no change in shear force of muscle fibers. Moreover, the results were conflicting with those results reported in literature since Zebu breeds are recognized by greater shear force of muscle fibers in relation to European cattle breeds (LAGE et al., 2012). The lower tenderness of zebu meat is due to the high concentrations of muscle calpastatin, which inhibits the calpain enzyme that is responsible for the softening during postmortem storage. Furthermore, the lower tenderness of zebu meat is related to the greater amount of insoluble collagen (LIMA JÚNIOR et al., 2011) and higher pre-slaughter excitability, resulting in lower available glycogen and lower $\mathrm{pH}$ fall during postmortem storage (LOPES et al., 2012). 
The proportion of silage in the rations, and the genetic group of animals did not affect fluid loss during thawing and cooking $(\mathrm{P}>0.05$; Table 5). These results are similar to those observed by Missio et al. (2010) and Cruz et al. (2015b), who found no change in these characteristics in young bulls fed in confinement with different levels of concentrate in the rations. This was attributed to the similar meat marbling content. It is worth mention, that the presence of fluid in the muscle is because of the water retention capacity of muscle proteins, particularly myofibril, which can bind large amounts of water by hydrogen bonds to the polar groups of proteins. The amount of water decreases as the polar groups are blocked. Thus, when post-mortem glycolysis is faster, a lower $\mathrm{pH}$ can be obtained at a higher temperature, decreasing the water retention capacity (HUFF-LONERGAN et al., 2005). Thus, one can expect greater liquid loss in zebu meat because of the higher consumption of muscle glycogen as a result of their higher pre-slaughter excitability (LOPES et al., 2012). However, Rocha Júnior et al. (2010) found no change in final pH of Nellore or crossbreed meat (1/2 Holstein 1/4 Gir $1 / 4$ Nellore), what would justify a similar loss of fluids during thawing and cooking, as occurred in this study. Corroborating, Maggioni et al. (2012), after evaluating meat characteristics of different genetic groups (Nellore, 1/2 Limousin-1/2 Nellore or 1/2 Red Angus-1/2 Nellore) and carcass finishing ( 3 and $5 \mathrm{~mm}$ ), found that Nellore meat showed lower water losses during thawing and cooking at the lower carcass finish over other genotypes that showed similarity to these characteristics, a fact attributed to the carcasses $\mathrm{pH}$.

\section{Conclusions}

Rations containing up to $400 \mathrm{~g} \mathrm{~kg}^{-1}$ of grass silage have no major impact on the proportion of commercial cuts or the meat yield of the carcass, with marked losses only for marbling in young Nellore bulls. Nevertheless, young Nellore bulls generate carcasses with a higher yield of noble cuts in relation to dairy crossbreed young bulls independent of the proportion of silage in the diets.

\section{References}

ALBERTÍ, P.; PANEA, B.; SAÑUDO, C.; OLLETA, J. L.; RIPOLL, G.; ERTBJERA, P.; CHRISTENSEN, M.; GIGLI, S.; FAILLA, S.; CONCETTI, S.; HOCQUETTE, J. F.; JAILLER, R.; RUDEL, S.; RENAND, G.; NUTE, G. R.; RICHARDSON, R. I.; WILLIAMS, J. L. Live weight, body size and carcass characteristics of young bulls of fifteen European breeds. Livestock Science, New York, v. 114, n. 1, p. 19-30, 2008.

ALBRECHT, E.; TEUSCHER, F.; ENDER, K.; WEGNER, J. Growth- and breed-related changes of marbling characteristics in cattle. Journal of Animal Science, Champaign, v. 84, n. 5, p. 1067-1075, 2006.

ALVES, D. D.; PAULINO, M. F.; BACKES, A. A.; VALADARES FILHO, S. C.; RENNÓ, L. N. Características de carcaça de bovinos Zebu e cruzados Holandês-Zebu $\left(\mathrm{F}_{1}\right)$ nas fases de recria e terminação. Revista Brasileira de Zootecnia, Viçosa, MG, v. 33, n. 5, p. 1274-1284, 2004.

ASSOCIATION OF OFFICIAL ANALYTICAL CHEMISTS - AOAC. Official methods of analysis. $16^{\text {th }}$ ed. Arlington: AOAC International, 1995. $1025 \mathrm{p}$.

CRUZ, R. S.; ALEXANDRINO, E.; MISSIO, R. L.; NEIVA, J. N. M.; RESTLE, J.; MELO, J. C.; PAULA NETO, J. J.; SILVA, D. P.; DUARTE, T. D.; SILVA, A. A. M. Características das carcaças e carne de tourinhos Nelore alimentados com níveis de concentrado e farelo do mesocarpo de babaçu. Arquivo Brasileiro de Medicina Veterinária e Zootecnia, Belo Horizonte, v. 67, n. 1, p. 299-308, 2015b.

CRUZ, R. S.; ALEXANDRINO, E.; MISSIO, R. L.; RESTLE, J.; MELO, J. C.; PAULA NETO, J. J.; NEIVA, J. N. M.; MENDES FILHO, G. O.; SOUZA JÚNIOR, A.; DUARTE, T. D.; REZENDE, J. M.; SILVA, A. A. M. Desempenho bioeconômico de tourinhos alimentados com níveis de concentrado e farelo do mesocarpo de babaçu. Semina Ciências Agrárias, Londrina, v. 35, n. 4, p. 2159-2174, 2014.

CRUZ, R. S.; ALEXANDRINO, E.; MISSIO, R. L.; RESTLE, J.; MELO, J. C.; PAULA NETO, J. J.; SILVA, A. A. M.; SILVA, D. P. Níveis de concentrado e farelo do mesocarpo de babaçu sobre as características da carcaça de tourinhos confinados. Biosciense Journal, Uberlândia, v. 31, n. 1 , p. $73-86,2015 \mathrm{a}$. 
FERNANDES, H. J.; PAULINO, M. F.; MARTINS, R. G. R.; VALADARES FILHO, S. C.; TORRES, R. A.; PAIVA, L. M.; RIBEIRO, V. A. Crescimento de componentes corporais de três grupos genéticos nas fases de recria e terminação. Revista Brasileira de Zootecnia, Viçosa, MG, v. 34, n. 1, p. 288-296, 2005.

HANKINS, O. G.; HOWE, P. E. Estimation of the composition of beef carcasses and cuts. Washington: U.S. Department of Agriculture, 1946. v. 21, 926 p.

HUFF-LONERGAN, E.; LONERGAN, S. M. Mechanisms of water-holding capacity of meat: the role of postmortem biochemical and structural changes. Meat Science, New York, v. 71, n. 1, p. 194-204, 2005.

LAGE, J. F.; PAULINO, P. V.; VALADARES FILHO, S. C.; SOUZA, E. J.; DURARTE, M. S.; SOUZA, N. K.; COX, R. B. Influence of genetic type and level of concentrate in the finishing diet on carcass and meat quality traits in beef heifers. Meat Science, New York, v. 90, n. 3, p. 770-774, 2012.

LEME, P. R.; BRITO, C.; MARGARIDO, R. C. C.; TEDESCHI, L. O.; HAUSKNECHT, J. C. O. V.; ALLEONI, G. F.; LUCHIARI FILHO, A. desempenho em confinamento e características de carcaça de bovinos machos de diferentes cruzamentos abatidos em três faixas de peso. Revista Brasileira de Zootecnia, Viçosa, MG, v. 29, n. 6, p. 2347-2353, 2000. Suplemento 2.

LIMA JÚNIOR, D. M.; RANGEL, A. H. N.; URBANO, S. A.; MACIEL, M. V.; AMARO, L. P. A. Alguns aspectos qualitativos da carne bovina: uma revisão. Acta Veterinaria Brasilica, Brasília, v. 5, n. 4, p. 351-358, 2011.

LOPES, L. S.; LADEIRA, M. M.; MACHADO NETO, O. R.; PAUlinO, P. V. R.; CHIZZOTTI, M. L.; RAMOS, E. M.; OLIVEIRA, D. M. Características de carcaça e cortes comerciais de tourinhos Red Norte e Nelore terminados em confinamento. Revista Brasileira de Zootecnia, Viçosa, MG, v. 41, n. 4, p. 970-977, 2012.

MAGGIONI, D.; PRADO, I. N.; ZAWADZKI, F.; VALERO, M. V.; MARQUES, J. A.; BRIDI, A. M.; MOLETTA, J. L.; ABRAHÃO, J. J. S. Grupos genéticos e graus de acabamento sobre qualidade da carne de bovinos. Semina: Ciências Agrárias, Londrina, v. 33, n. 1, p. 391-402, 2012.

MCGEE, M.; KEANE, M. G.; NEILAN, R.; MOLONEY, R.; CAFFREY, P. J. Non-carcass parts and carcass composition of high dairy genetic merit Holstein, standard dairy genetic merit Friesian and Charolais $x$ Holstein-Friesian steers. Irish Journal of Agricultural and Food Research, Teagasc, v. 47, n. 1, p. 41-51, 2008.

MENEZES, L. F. G.; BRONDANI, I. L.; ALVES FILHO,
D. C.; RESTLE, J.; ARBOITTE, M. Z.; FREITAS, L. S.; PAZDIORA, R. D. Características da carcaça de novilhos de diferentes grupos genéticos, terminados em confinamento, recebendo diferentes níveis de concentrado. Ciência Rural, Santa Maria, v. 35, n. 5, p. 1141-1147, 2005.

MIOTTO, F. R. C.; RESTLE, J.; NEIVA, J. M. N.; LAGE, M. E.; CASTRO, K. J.; ALEXANDRINO, E. Farelo do mesocarpo de babaçu na terminação de tourinhos: características da carcaça e cortes secundários do traseiro especial. Ciência Animal Brasileira, Goiânia, v. 13, n. 4, p. 440-449, 2012.

MISSIO, R. L.; BRONDANI, I. L.; ALVES FILHO, D. C.; RESTLE, J.; ARBOITTE, M. Z.; SEGABINAZZI, L. R. Características da carcaça e da carne de tourinhos terminados em confinamento, recebendo diferentes níveis de concentrado na dieta. Revista Brasileira de Zootecnia, Viçosa, MG, v. 39, n. 7, p. 1610-1617, 2010.

MÜLLER, L. Normas para avaliação de carcaças e concurso de carcaça de novilhos. Santa Maria: Universidade Federal de Santa Maria, 1987. 31 p.

NATIONAL RESEARCH COUNCIL - NRC. Nutrient requirements of beef cattle. $7^{\text {th }}$ ed. rev. Washington: National Academy of Sciences, 1996. 242 p.

OURY, M.; PIERRET, P.; COULMIER, D.; DUMONT, R. Eléménts de maîtrise de la couleur des viandes chez les bovins de race Charolaise. Inra Productions Animales, Clermont, Ferrand, v. 22, n. 2, p. 131-140, 2009.

PACHECO, R. F.; MAYER, A. R.; VAZ, M. A.; PÖTTER, L.; CATTELAN, J.; CALLEGARO, A. M.; PIZZUTI, L. A.; BRONDANI, I. L.; ALVES FILHO, D. C.; PACHECO, P. S. Qualitative characteristics of meat from cull cows of different genotypes and age class slaughter under different finishing systems: a metaanalytic approach. Anais da Academia Brasileira de Ciências, Rio de Janeiro, v. 87, n. 2, p. 1083-1093, 2015.

PETHICK, D. W.; HARPER, G. S.; ODDY, V. H. Growth, developpment and nutritional manipulation of marbling in cattle: a review. Australian Journal Experimental Agriculture, Queensland, v. 44, n. 7, p. 704-715, 2004.

PUTRINO, S. M.; LEME, P. R.; LUZ e SILVA, S.; MANELLA, M. Q.; NOGUEIRA FILHO, J. C. M.; LIMA, C. G.; ALLEONI, G. F. Digestibilidade aparente de dietas com níveis crescentes de concentrado em novilhos Brangus e Nelore. Arquivo Brasileiro de Medicina Veterinária e Zootecnia, Belo Horizonte, v. 59, n. 2, p. 406-413, 2007.

RIPOLI, M. V.; ROGBERG-MUÑOZ, A.; LIRÓN, J. P.; FRANCISCO, E.; VILLEGAS-CASTAGNASSO, E. E.; PERAL-GARCIA, P.; GIOVAMBATTISTA, G. History 
and selection imprinting on genetic relationships among bovine breeds analyzed trough five genes related with marbling. Research in Veterinary Science, New York, v. 90, n. 2, p. 245-252, 2011.

ROCHA JÚNIOR, V. R.; SILVA, F. V.; BARROS, R. C.; REIS, S. T.; COSTA, M. D.; SOUZA, A. S.; CALDEIRA, L. A.; OLIVEIRA, T. S.; OLIVEIRA, L. L. S. Desempenho e características de carcaça de bovinos Nelore e mestiços terminados e confinamento. Revista Brasileira de Saúde e Produção Animal, Salvador, v. 11, n. 3, p. 865-875, 2010.

SCHERTZ, M. J.; GARMYN, A. J.; RATHMANN, R. J.; KELLERMEIER, J. D.; JACKSON, S. P.; RAMSEY, C. B.; WILLIAMS, F. L.; MILLER, M. F. Estimation of live quality grade in multiple biological types of beef slaughter steers and the relationship to carcass quality. The Professional Animal Scientist, New York, v. 27, n. 4, p. 328-335, 2011.

SILVA, A. H. G.; RESTLE, J.; MISSIO, R. L.; BILEGO, U. O.; FERNANDES, J. J. R.; REZENDE, P. L. P.; SILVA, R. M.; PEREIRA, M. L. R.; LINO, F. A. Milheto em substituição ao milho na dieta de novilhos confinados. Semina: Ciências Agrárias, Londrina, v. 35, n. 4, p. 2077-2094, 2014.
SILVEIRA, M. F.; BRONDANI, I. L.; ARBOITTE, M. Z.; ALVES FILHO, D. C.; RESTLE, J.; PIZZUTI, L. A. D.; LUZ, T. R. R.; RETORE, M. Composição física da carcaça e qualidade da carne de novilhos Charolês e Nelore que receberam diferentes proporções de concentrado na dieta. Arquivo Brasileiro de Medicina Veterinária e Zootecnia, Belo Horizonte, v. 61, n. 2, p. 467-474, 2009.

SNIFFEN, C. J.; O'CONNOR, J. D.; VAN SOEST, P. J.; FOX, D. G.; RUSSEL, J. B. A net carbohydrate and protein system for evaluating cattle diets: II. Carbohydrate and protein availability. Journal of Animal Science, Champaign, v. 70, n. 11, p. 3562-3577, 1992.

VAN SOEST, P. J.; ROBERTTSON, J. B.; LEWIS, B. A. Methods for dietary fiber, neutral detergent fiber, and nonstarch polysaccharides in relation to animal nutrition. Journal of Dairy Science, Champaign, v. 74, n. 10, p. 3583-3597, 1991.

VAZ, F. N.; RESTLE, J. Efeito de raça e heterose para características de carcaça de novilhos da primeira geração de cruzamento entre Charolês e Nelore. Revista Brasileira de Zootecnia, Viçosa, MG, v. 30, n. 2, p. 409416, 2001. 
